\title{
INTANGIBLE ASSET, PROFITABILITAS, DAN SUSTAINABILITY REPORT TERHADAP NILAI PERUSAHAAN
}

\author{
Annisa Marwa \\ annisamarwa15@gmail.com \\ Deannes Isynuwardhana \\ Annisa Nurbaiti \\ Fakultas Ekonomi dan Bisnis, Universitas Telkom
}

\begin{abstract}
Sri-Kehati Index has been increased since 2009, though return on equity has decreased. Should, stock price will be affected by the ROE so that the value of the firm also decreases. In this study, the independent variables are intangible assets, profitability, and sustainability report. The dependent variable is the value of the firm. This study aims to determine the effect of intangible assets, profitability, and sustainability report on the value of the firm at a company registered in Sri-Kehati Index Indonesia Stock Exchange. The population are all companies registered in SriKehati Index period 2009-2014, while the sample is determined by purposive sampling method so as to obtain 5 companies. The analytical method used is the panel data regression analysis. The results show intangible assets, profitability, and sustainability report simultaneously significant effect on value of the firm. While partially intangible asset has significant negative effect and profitability has significant positive effect on value of the firm.
\end{abstract}

Keywords : intangible asset, profitability, sustainability report, and value of the firm

\begin{abstract}
Abstrak
Pertumbuhan Indeks Sri-Kehati terus meningkat dibentuk tahun 2009, sedangkan return on equity ROE cenderung menurun. Seharusnya, harga saham akan terpengaruh oleh $R O E$ sehigga nilai pasar perusahaan juga menurun. Dalam penelitian ini variabel independen adalah intangible asset, profitabilitas, dan sustainability report, sedangkan variabel dependen adalah nilai perusahan. Penelitian ini bertujuan untuk mengetahui pengaruh intangible asset, profitabilitas, dan sustainability report terhadap nilai perusahan pada perusahaan yang terdaftar di Indeks SriKehati Bursa Efek Indonesia. Populasi adalah seluruh perusahaan yang terdaftar di Indeks SriKehati periode 2009-2014, sedangkan sampel ditentukan dengan metode purposive sampling yaitu 5 perusahaan. Metode analisis yang digunakan adalah analisis regresi data panel. Hasil penelitian menunjukkan intangible asset, profitabilitas, dan sustainability report secara simultan berpengaruh signifikan terhadap nilai perusahaan. Secara parsial intangible asset berpengaruh signifikan negatif dan profitabilitas berpengaruh signifikan positif terhadap nilai perusahaan.
\end{abstract}

Kata Kunci : intangible asset, profitabilitas, sustainability report, dan nilai perusahaan 


\section{PENDAHULUAN}

Indeks Sri-Kehati adalah kumpulan dari sahamsaham yang fokus utamanya tidak hanya memperoleh keuntungan namun juga tetap memperhatikan kelestarian lingkungan. Pergerakan indeks saham SriKehati mengalami fluktuasi yang meningkat sejak diterbitkan pada tahun 2009, artinya nilai perusahaan yang terdaftar pada indeks Sri-Kehati juga mengalami peningkatan. Berikut merupakan grafik perkembangan harga saham penutupan (closing price) dan ROE pada Indeks Sri-Kehati periode 2009 -2014.

Berdasarkan faktor fundamental perusahaan (www. sahamok.com), hal yang terjadi pada indeks Sri-Kehati pada gambar 1 return on equity cenderung menurun. Artinya perusahaan memperoleh hasil atas dana yang telah diinvestasikan oleh pemegang saham baik secara langsung atau dengan laba yang telah ditahan cenderung menurun tiap tahunnya selama periode 2009-2014. Sedangkan realita yang terjadi pada harga pasar saham pada indeks Sri-Kehati terus meningkat. Seharusnya, harga saham akan terpengaruh oleh return on equity sehigga nilai perusahaan juga ikut menurun. Berdasarkan gambar 1 tersebut menunjukkan fenomena bahwa harga saham cenderung meningkat sehingga nilai perusahaan dapat dikatakan meningkat tanpa diikuti pertumbuhan positif return in equity selama periode 2009-2014.

Banyak faktor yang dapat mempengaruhi nilai perusahaan, salah satunya Intangible Asset. Pada tahun 2000-an, nilai Intangible Asset mendominasi nilai pasar perusahaan di pasar modal Amerika, yaitu bernilai sekitar 80\% dari nilai pasar perusahaan (Sullivan, 2000). Di Inggris, besarnya nilai aset tidak berwujud adalah $60 \%$ dari nilai pasar perusahaan (Pricewaterhouse Coopers, 2004) dalam Soraya dan Syafruddin (2013). Di Asia, perkembangan nilai aset tidak berwujud juga memiliki tren positif termasuk di negara Indonesia. Aset tidak berwujud merupakan hak, keistimewaan, dan manfaat kepemilikan atau pengendalian. Dua karakteristik umum aset tidak berwujud adalah tingginya ketidakpastian masa manfaat dan tidak adanya wujud fisik (Mawikere,Florence Katthy Jantje J. Tinangon, 2016). Intangible asset juga dikenal dengan intellectual assets, intellectual capital, intellectual property, atau knowledge capital (Erawati dan Sudana, 2009). Dalam penelitian ini intangible asset yang dimaksud adalah intellectual capital yang diproksikan menggunakan model VAICTM. Terdapat perbedaan penelitan sebelumnya mengenai aset tidak berwujud yaitu pengelolaan aset tidak berwujud yang semakin baik akan meningkatkan nilai perusahaan (Widhiastuti, Ni Luh , 2015). Hasil yang berbeda ditemukan oleh Yuniasih (2010) dalam penelitian menemukan bahwa intellectual capital berpengaruh negatif terhadap nilai perusahaan.

Selain aset tidak berwujud (Intangible Asset), faktor yang mempengaruhi nilai perusahaan adalah profitabilitas. Hal ini didukung oleh penelitian Setia (2008). Faktor- faktor yang mempengaruhi nilai perusahaan, yaitu : keputusan pendanaan, kebijakan dividen, keputusan investasi, struktur modal, profitabilitas, leverage, pertumbuhan perusahaan, ukuran perusahaan. Profitabilitas dapat didefinisikan sebagai hasil bersih dari berbagai kebijaksanaan dan keputusan yang diterapkan oleh sebuah perusahaan. Selain dari itu, profitabilitas didefinisikan sebagai kemampuan perusahaan menghasilkan laba dari penjualan barang atau jasa yang diproduksinya. Nilai dari suatu perusahaan dipengaruhi oleh besar kecilnya profitabilitas yang dihasilkan oleh perusahaan tersebut, karena semakin besarnya profitabilitas akan membuat nilai perusahaan semakin tinggi dan membuat investor berani berinvestasi di perusahaan tersebut.

Penelitian sebelumnya menurut Nurmayasari (2012), Prastika (2012), dan Almajali (2012) menemukan bahwa profitabilitas berpengaruh positif terhadap nilai perusahaan sedangkan Munawaroh, aisyatul (2015). menyatakan bahwa ROA menunjukkan pengaruh signifikan negatif terhadap nilai perusahaan. Dalam peneliatian lain ROA dapat mempengaruhi nilai perusahaan menggunakan Tobin's Q (Sucuahi, W dan Cambarihan, 2016).

Di Indonesia beberapa literatur menyebutkan bahwa terdapat faktor lain yang mempengaruhi nilai perusahaan seperti penelitian Wibowo, I. dan Faradiza, S. A. (2014). menyatakan bahwa sebagian besar perusahaan di Indonesia hanya berfokus pada laporan keuangan saja. Padahal kinerja keuangan tidak relevan lagi, harus ada informasi tambahan yang di laporkan oleh manajemen perusahaan agar menarik minat investor yakni sustainability report. Bagi perusahaan sustainability report merupakan alat ukur pencapaian target kerja dalam isu Triple Bottom Line. Bagi investor sustainability report berfungsi sebagai alat kontrol atas pencapaian kinerja perusahaan sekaligus sebagai media pertibangan investor dalam mengalokasikan sumber daya finansialnya. Sementara bagi pemangku kepentingan lainnya menjadi tolak ukur untuk menilai kesungguhan komitmen perusahaan terhadap pembangunan berkelanjutan (Wibowo, I. dan Faradiza, S. A. 2014).

Selain itu terdapat ketidak konsistenan hasil peneliti terdahulu. Menurut Utami, Wiwik (2015). Pengungkapan Sustainability Report berpengaruh positif signifikan terhadap nilai perusahaan. Berbanding terbalik dengan penelitian oleh Tarigan Josua dan Semuel Hatane (2014). bahwa dimensi ekonomi (EC) dari Sustainability Report tidak berpengaruh terhadap nilai perusahaan. Namun demikian kedua hipotesis yang lain menunjukkan bahwa dimensi lingkungan (EN) dan dimensi sossial (SO) dari Sustainability Report berpengaruh negatif terhadap nilai perusahaan.

Secara empiris, penelitian ini menguji apakah Intangible Asset dan Profitabilitas dan Sustainability 
Report secara signifikan terhadap Nilai Perusahaan yang terdaftar di Indeks Sri Kehati di BEI Periode 20102014". Berdasarkan perumusan masalah yang telah diuraikan tersebut, maka tujuan penelitian ini adalah :

1. Untuk mengetahui pengaruh Intangible Asset dan Profitabilitas dan Sustainability Report terhadap Nilai Perusahaan pada yang terdaftar di Indeks Sri Kehati di BEI Periode 2009-2014.

2. Untuk mengetahui pengaruh secara simultan Intangible Asset dan Profitabilitas dan Sustainability Report terhadap Nilai Perusahaan pada perusahaan yang terdaftar di Indeks Sri Kehati di BEI Periode 2009-2014.

3. Untuk mengetahui pengaruh secara parsial Intangible Asset terhadap Nilai Perusahaan pada perusahaan yang terdaftar di Indeks Sri Kehati di BEI Periode 2009-2014.

4. Untuk mengetahui pengaruh secara parsial Profitabilitas terhadap Nilai Perusahaan pada perusahaan yang terdaftar di Indeks Sri Kehati di BEI Periode 2009-2014.

5. Untuk mengetahui pengaruh secara parsial Sustainability Report terhadap Nilai Perusahaan pada perusahaan yang terdaftar di Indeks Sri Kehati di BEI Periode 2009-2014.

Penelitian ini diharapkan dapat membantu perusahaan dalam mempertimbangkan faktor-faktor yang mempengaruhi nilai perusahaan diantaranya intangible Asset, profitabilitas, dan sustainability report dan bahan evaluasi bahwa di Indeks saham Sri Kehati sesuatu yang bisa meningkatkan reputasi perusahaan.

Dalam penelitian ini yang menjadi variabel terikat atau variabel dependen adalah Nilai Perusahaan yang diproksi dengan Tobin's Q. Variabel independen sebagai variabel bebas atau variabel tidak terikat yang mempengaruhi Nilai Perusahaan adalah Intangible Asset yang diproksi dengan VAIC ${ }^{\text {TM }}$ model, Profitabilitas dengan Return on Asset, Sustainability Report dengan SRDI.

Kieso et al (2013) yang menyatakan bahwa "intangible assets dapat dibedakan berdasarkan empat karakteristik, yaitu identifiability, manner of acquisition, expected period of benefit, dan sparebility from entire enterprise."

Aset tak berwujud didefinisikan dalam paragraf 8 PSAK 19 (Revisi 2010) sebagai aset nonmoneter teridentifikasi tanpa wujud fisik. Aset tak berwujud merupakan komponen intellectual capital yang penting dan memiliki dampak sangat nyata bagi perusahaan (Stanfield tahun 1999 dalam Soraya L dan Syafruddin M, 2013).

Intangible asset juga dikenal dengan intellectual assets, intellectual capital, intellectual property, atau knowledge capital (Erawati dan Sudana, 2009). Dalam penelitian ini Intangible asset menggunakan proksi dari intellectual capital yaitu model VAICTM. Salah satu sumber modal perusahaan adalah Intellectual capital dengan memberikan keunggulan kompetitif dan nilai tambah. Intellectual capital yang dapat dikelola secara maksimal akan memberikan pengaruh signifikan pada pengambilan keputusan investor sehingga memberikan kontribusi positif pada laba bersih perusahaan dan meningkatkan nilai perusahaan terutama pada nilai pasarnya.

Profitabilitas adalah kemampuan perusahaan untuk menghasilkan profit atau laba selama satu tahun yang dinyatakan dalam rasio laba operasi dengan penjualan dari data laporan laba rugi akhir tahun (Sujoko dan Soebiantara 2007 dalam Moniaga F, 2013). Dalam penelitian ini profitabilitas menggunakan proksi return on asset. Menurut Hery (2015) return on asset adalah rasio yang mengukur seberapa jumlah laba bersih yang akan dihasilkan dari setiap rupiah dana yang tertanam dalam total aset.

Penelitian yang dilakukan oleh Sucuahi W dan Cambarihan Jay M (2016) menyatakan bahwa profitabilitas berpengaruh positif terhadap nilai perusahaan. Pernyataan tersebut didukung oleh beberapa peneliti seperti Ju Chen dan Yu Chen (2011), Gill dan Obradovich (2012), Hermuningsih (2013) yang juga menyatakan bahwa profitabilitas berpengaruh positif signifikan.

Profitabilitas menggunakan Return on Asset dapat digunakan dalam mengkukur tingkat keuntungan yang diperoleh perusahaan dengan cara membandingkan laba setelah pajak dengan rata-rata total aset. Artinya keuntungan yang diperoleh atas asset yang dimiliki perusahaan. Semakin tinggi ROA maka semakin besar nilai profitabilitas perusahaan, yang pada akhirnya akan meberi sinyal positif bagi investor dalam melakukan investasi pada perusahaan.

Sustainability Reporting adalah praktik pengukuran, pengungkapan, dan akuntabilitas kepada stakeholders baik internal maupun eksternal perusahaan mengenai kinerja organisasi dalam mencapai tujuan pembangunan berkelanjutan (Sustainable Development) GRI-G4 (2013).

Tujuan utama perusahaan adalah meningkatkan nilai perusahaan. Nilai perusahaan akan terjamin tumbuh secara berkelanjutan apabila perusahaan memperhatikan dimensi ekonomi, lingkungan hidup, dan sosial karena keberlanjutan merupakan keseimbangan antara ketiga dimensi tersebut. Perkembangan ekonomi dengan memperhatikan dampak lingkungan karena adanya perusaahaan, dana sosial untuk program Corporate Social Rensposibility dilaporkan dalam bentuk sustainability report. Pengungkapan sustainability report dapat meningkatkan nilai perusahaan dilihat dari harga saham diperusahaan. Hal ini didukung oleh Utami Wiwik (2015), Susanto dan Tarigan, Adima (2012) bahwa sustainability report memberikan pengaruh positif signifikan terhadap nilai perusahaan.

Sustainability Reporting adalah cara organisasi dalam memantau dan mengkomunikasikan kinerja ekonomi, sosial dan lingkungan serta dapat memberi 
daya tarik terhadap para pemegang saham menganai visi jangka panjang perusahaan dan membei nilai lebih pada perusahaan apabila dari segi profit cenderung tidak meyakinkan. Tujuan perusahaan dapat terpenuhi dengan menerbitkan sustainability reporting untuk menarik minat investor menanam saham di perusahaan sehingga nilai perusahaan meningkat.

Hubungan antara intellectual asset, profitabilitas, dan sustainability report. Terhadap nilai perusahaan digambarkan dalam bentuk kerangka pemikiran yang tersaji dalam Gambar 2.

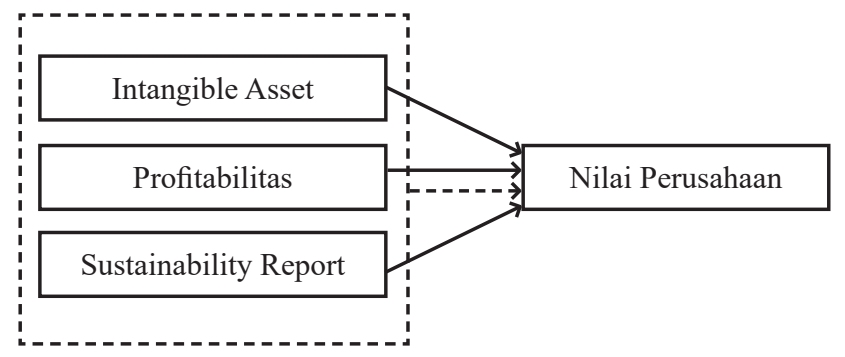

Keterangan :

$\begin{array}{ll}\text { Parsial } & : \longrightarrow \\ \text { Simultan } & :-\cdots\end{array}$

Gambar 2. Kerangka Pemikiran

Variabel pada penelitian ini menggunakan dua variabel, yaitu variabel independen dan variabel dependen. Variabel bebas dalam penelitian ini meliputi : intangible asset, profitabilitas dan sustainability report. Variabel dependen yang digunakan dalam penelitian ini adalah pengungkapan nilai perusahaan.

\section{METODE}

Populasi yang digunakan dalam penelitian ini adalah perusahaan yang terdaftar di indeks Sri-kehati tahun 2009-2014. Teknik sampling yang digunakan adalah purposive sampling dengan kriteria yaitu: 1) Perusahaan yang konsisten terdaftar dalam indeks Sri-Kehati di Bursa Efek Indonesia tahun 2009-2014, 2) Perusahaan non sektor keuangan dalam indeks Sri-Kehati di Bursa Efek Indonesia tahun 2009-2014, 3) Perusahaan yang menerbitkan laporan tahunan pada tahun 2009-2014, 4) Perusahaan yang menerbitkan Sustainability Report pada tahun 2009-2014. Sehingga, diperoleh data observasi sebanyak 48 yang terdiri dari 5 perusahaan dengan periode penelitian selama enam tahun. Teknik analisis yang digunakan dalam penelitian ini adalah analisis deskriptif dan analisis regresi data panel.

Populasi menurut Sugiyono (2013:117) adalah wilayah generalisasi yang terdiri atas objek atau subjek yang mempunyai kualitas dan karakteristik tertentu yang ditetapkan oleh peneliti untuk dipelajari dan kemudian ditarik kesimpulannya. Populasi bukan sekedar jumlah yang ada pada objek atau subjek yang dipelajari, tetapi meliputi seluruh karakteristik yang dimiliki oleh subjek atau objek itu. Populasi dalam penelitian ini menggunakan perusahaan yang terdaftar dalam Indeks Sri-Kehati di Bursa Efek Indonesia (BEI) tahun 2009-2014

Teknik pengambilan sampel yang digunakan adalah teknik purposive sampling, yaitu teknik penentuan sampel dengan pertimbangan tertentu. Pada penelitian ini, perusahaan keuangan tidak termasuk dalam kriteria sampel dikarenakan pengukuran profitabilitas yang berbeda. Kriteria dalam pengambilan sampel sebagai berikut:

1. Perusahaan yang konsisten terdaftar dalam indeks SRI-Kehati di Bursa Efek Indonesia pada tahun 2009-2014.

2. Perusahaan non Sektor Keuangan dalam Indeks Sri Kehati pada tahun 2009-2014.

3. Perusahaan yang menerbitkan laporan tahunan, laporan keuangan, dan sustainability report pada tahun 2009-2014.

4. Perusahaan yang menerbitkan Sustainability Report dengan data lengkap pada tahun 2009-2014

Tabel 2. Kriteria Pengambilan Sampel

\begin{tabular}{|c|c|c|}
\hline No. & Keterangan & Jumlah \\
\hline 1. & $\begin{array}{l}\text { Perusahaan yang konsisten terdaftar di indeks } \\
\text { SRI KEHATI di Bursa Efek Indonesia pada } \\
\text { tahun 2009-2014. }\end{array}$ & 15 \\
\hline 2. & $\begin{array}{l}\text { Perusahaan Sektor Keuangan dalam Indeks Sri } \\
\text { Kehati pada tahun 2009-2014. }\end{array}$ & (4) \\
\hline 3. & $\begin{array}{l}\text { Perusahaan yang tidak menerbitkan laporan } \\
\text { tahunan dan laporan keuangan pada tahun 2009- } \\
2014 \text {. }\end{array}$ & (1) \\
\hline 4. & $\begin{array}{l}\text { Perusahaan yang tidak menerbitkan dan data } \\
\text { variabeltidak lengkap pada Sustainability Report } \\
\text { pada tahun 2009-2014. }\end{array}$ & (5) \\
\hline \multirow[t]{2}{*}{5.} & $\begin{array}{l}\text { Jumlah sampel yang dijadikan dalam obyek } \\
\text { penelitian }\end{array}$ & 5 \\
\hline & Jumlah data ( $5 \times 6$ tahun $)$ & 30 \\
\hline
\end{tabular}

Sumber : Data diolah penulis (2016)

Tabel 2 menunjukkan kriteria pengambilan sampel terlihat bahwa sampel yang diambil adalah 5 perusahaan yang terdaftar di Bursa Efek Indonesia pada Indeks Sri Kehati.

Tabel 3. Sampel Perusahaan

\begin{tabular}{llc}
\hline No. & \multicolumn{1}{c}{ Nama Perusahaan } & Kode \\
\hline 1 & Aneka Tambang Tbk & ANTM \\
2 & Astra Internasional Tbk & ASII \\
3 & Perusahaan Gas Negara (Persero) Tbk & PGAS \\
4 & Tambang Batubara Bukit Asam (Persero) Tbk & PTBA \\
5 & Telekomunikasi Indonesia (Persero) Tbk & TLKM \\
\hline
\end{tabular}

Sumber : Data diolah penulis (2016) 
Hasil analisis statistik deskriptif ditunjukkan pada Tabel 4.

Tabel 4. Hasil Statistik Deskriptif

\begin{tabular}{lcccc}
\hline & IA & ROA & SR & TOBIN'S Q \\
\hline Mean & 3.8121 & 0.1562 & 0.6751 & 1.5912 \\
Maksimum & 7.5395 & 0.3378 & 0.9341 & 3.4621 \\
Minimum & -2.3600 & -0.0338 & 0.1538 & 0.4039 \\
Std. Dev & 1.7208 & 0.0714 & 0.2684 & 0.7600 \\
Observations & 30 & 30 & 30 & 30 \\
\hline
\end{tabular}

Sumber : Data yang telah diolah oleh penulis (2017)

Tabel 4 menunjukkan bahwa seluruh variabel memiliki nilai mean yang lebih besar dibandingkan standar deviasi yang dapat diartikan bahwa data variabel operasional tersebut berkelompok dan tidak bervariasi.

Nilai rata-rata intangible asset pada perusahaan yang terdaftar di Indeks Sri-Kehati Bursa Efek Indonesia tahun 2009-2014 sebesar 3.8121. Nilai tersebut menunjukkan bahwa nilai VAIC ${ }^{\text {TM }}$ perusahaan pada Indeks Sri-Kehati berdasarkan klasifikasi pada penelitian Ulum (2008). termasuk dalam kategori "common performers". Nilai rata-rata perusahaan pada Indeks Sri-Kehati setiap tahunnya berfluktuatif. Nilai maksimum variabel intangible asset adalah sebesar 7.5395 termasuk kategori "top performers" dan nilai minimum sebesar -2.3600 termasuk kategori "bad performers". Selain itu, standar deviasi selama tahun 2009-2014 menunjukkan nilai sebesar 1.7208 yang lebih rendah dari nilai rata-rata, sehingga menunjukkan bahwa intangible asset tahun 2009-2014 berkelompok atau tidak bervariasi.

Nilai rata-rata profitabilitas pada perusahaan yang terdaftar di Indeks Sri-Kehati Bursa Efek Indonesia tahun 2009-2014 sebesar 0.1562. Nilai tersebut menunjukkan bahwa kemampuan perusahaan yang terdaftar di Indeks Sri-Kehati dalam menghasilkan profitabilitas. Artinya dari total aktiva yang dipergunakan operasi perusahaan yang terdaftar di Indeks Sri-Kehati mampu memberikan laba sebesar 0.1562. Selama periode 2009-2014 nilai maksimum variabel profitabilitas sebesar 0.3378 dan nilai minimum -0.0338. Selain itu, standar deviasi selama tahun 2009-2014 menunjukkan nilai sebesar 0.0714. Berdasarkan hasil tersebut profitabilitas tahun 2009-2014 berkelompok atau tidak bervariasi.

Nilai rata-rata sustainability report pada perusahaan yang terdaftar di Indeks Sri-Kehati Bursa Efek Indonesia tahun 2009-2014 sebesar 0.6751. Artinya rata-rata perusahaan pada Indeks Sri-Kehati yang menerbitkan sustainability report sebesar 0.6751 . Selama periode 2009-2014 nilai maksimum variabel sustainability report sebesar 0.9341 dan nilai minimum 0.1538 . Selain itu, standar deviasi selama tahun 2009-2014 menunjukkan nilai sebesar 0.2684. Berdasarkan hasil tersebut sustainability report tahun 2009-2014 berkelompok atau tidak bervariasi.

Nilai rata-rata nilai perusahaan pada perusahaan yang terdaftar di Indeks Sri-Kehati Bursa Efek Indonesia tahun 2009-2014 sebesar 1.5912. Nilai tersebut menunjukkan bahwa nilai Tobin's Q perusahaan pada Indeks Sri-Kehati memiliki prospek pertumbuhan yang dinilai oleh para investor sebesar 1.5912. Selama periode 2009-2014 nilai maksimum variabel nilai perusahaan sebesar 3.4621 dan nilai minimum 0.4039. Selain itu, standar deviasi selama tahun 2009-2014 menunjukkan nilai sebesar 0.7600. Berdasarkan hasil tersebut nilai perusahaan tahun 2009-2014 berkelompok atau tidak bervariasi.

Tabel 5. Hasil Uji Fixed Effect

\begin{tabular}{lccc}
\hline Effects Test & Statistic & d.f. & Prob. \\
\hline Cross-section F & 9.136519 & $(4,22)$ & 0.0002 \\
Cross-section Chi-square & 29.363148 & 4 & 0.0000 \\
\hline
\end{tabular}

Sumber: Data yang telah diolah oleh penulis (2017)

Berdasarkan hasil uji signifikansi fixed effect, diperoleh nilai probabilitas cross section Chi-square sebesar 0,0000 lebih kecil dari taraf signifikansi 5\% dan nilai prob cross section $\mathrm{F}$ sebesar 0,0002 lebih kecil dari taraf signifikansi 5\%, maka H1 diterima atau penelitian ini menggunakan metode fixed effect. Selanjutnya dilakukan pengujian antara metode fixed effect dengan random effect menggunakan uji Hausman.

Tabel 6. Hasil Uji Random Effect

\begin{tabular}{lccc}
\hline Test Summary & Chi-Sq. & Chi-Sq. & \multirow{2}{*}{ Prob. } \\
& Statistic & d.f. & \\
\hline Cross-section random & 1.115406 & 3 & 0.7734 \\
\hline
\end{tabular}

Sumber: Data yang telah diolah oleh penulis (2017)

Nilai probabilitas cross section random (p-value) sebesar 0,7734 >0,05, maka sesuai dengan ketentuan pengambilan keputusan bahwa $\mathrm{H} 1$ ditolak yaitu regresi data panel menggunakan metode random effect. Maka metode yang tepat digunakan pada penelitian ini adalah metode random effect.

Berdasarkan pengujian model yang dilakukan, maka model yang digunakan dalam regresi data panel pada penelitian ini adalah model Random Effect. Tabel 4 merupakan hasil uji dengan model Random Effect.

Tabel 7. Model Random Effect

\begin{tabular}{lrrrr}
\hline Variable & Coefficient & Std. Error & t-Statistic & Prob. \\
\hline C & 1.579373 & 0.582318 & 2.712217 & 0.0117 \\
IA & -0.127356 & 0.060981 & -2.088443 & 0.0467 \\
ROA & 43.55125 & 15.73619 & 2.767586 & 0.0103 \\
SR & 0.290855 & 0.519467 & 0.559911 & 0.5803 \\
\hline \multicolumn{5}{c}{ Weighted Statistics } \\
\hline
\end{tabular}




\begin{tabular}{|c|c|c|c|}
\hline$R$-squared & 0.343483 & Mean dependent var & 0.342910 \\
\hline $\begin{array}{l}\text { Adjusted } \\
\text { R-squared }\end{array}$ & 0.267731 & S.D. dependent var & 0.514418 \\
\hline $\begin{array}{l}\text { S.E. of } \\
\text { regression }\end{array}$ & 0.440201 & Sum squared resid & 5.038206 \\
\hline F-statistic & 4.534318 & Durbin-Watson stat & 1.597448 \\
\hline $\begin{array}{l}\text { Prob } \\
\text { (F-statistic) }\end{array}$ & 0.010989 & & \\
\hline \multicolumn{4}{|c|}{ Unweighted Statistics } \\
\hline $\begin{array}{l}\text { R-squared } \\
\text { Sum }\end{array}$ & 0.166158 & Mean dependent var & 1.591247 \\
\hline $\begin{array}{l}\text { squared } \\
\text { resid }\end{array}$ & 13.96698 & Durbin-Watson stat & 0.576235 \\
\hline
\end{tabular}

Sumber: Data yang telah diolah oleh penulis (2017)

Model persamaan regresi data panel yang dibentuk dalam penelitian ini merupakan model Random Effect. Berdasarkan tabel 8 dapat diketahui nilai konstanta koefisien sehingga dapat dibentuk persamaan sebagai berikut:

$$
\begin{aligned}
\mathrm{Y}= & 1.579373-0.127356 \mathrm{IA}+43.55125 \mathrm{RO} \\
& +0.290855 \mathrm{SR}+\mathrm{e}
\end{aligned}
$$

Persamaan regresi data panel diartikan sebagai berikut :

1. Nilai Konstanta sebesar 1.579373 menunjukkan bahwa apabila variabel independen pada regresi yaitu IA, ROA, dan SR bernilai nol, maka nilai perusahaan (Tobins' $Q$ ) yang dimiliki perusahaan di Indeks Sri-Kehati adalah sebesar 1.579373.

2. Kooefisien regresi IA $\left(\mathrm{x}_{1}\right)$ sebesar -0.127356 bertanda negatif menunujukkan apabila terjadi perubahan kenaikan IA sebesar 1 satuan (dengan asumsi variabel lain konstan) maka nilai perusahaan (Tobins'Q) yang dimiliki perusahaan yang dimiliki perusahaan di Indeks Sri-Kehati akan mengalami penurunan sebesar 0.127356 satuan.

3. Kooefisien regresi ROA $\left(\mathrm{x}_{2}\right)$ sebesar 43.55125 bertanda positif menunujukkan apabila terjadi perubahan kenaikan ROA sebesar 1 satuan (dengan asumsi variabel lain konstan) maka nilai perusahaan (Tobins'Q) yang dimiliki perusahaan yang dimiliki perusahaan di Indeks Sri-Kehati akan mengalami kenaikan sebesar 43.55125 satuan.

4. Kooefisien regresi SR $\left(\mathrm{x}_{3}\right)$ sebesar 0.290855 bertanda positif menunujukkan apabila terjadi perubahan kenaikan ROA sebesar 1 satuan (dengan asumsi variabel lain konstan) maka nilai perusahaan (Tobins'Q) yang dimiliki perusahaan yang dimiliki perusahaan di Indeks Sri-Kehati akan mengalami kenaikan sebesar 0.290855 satuan.

Berdasarkan hasil uji metode random effect model, diperoleh nilai Adjusted R2 (R-squared) sebesar
0.267731 atau $26,73 \%$. Hal ini mengindikasikan bahwa variabel independen yang terdiri dari Intangible Asset, profitabilitas, sustainability report yang mampu menjelaskan variabel dependen yaitu nilai perusahaan sebesar 26,73\% sedangkan sisanya 73,33 dijelaskan oleh variabel lain di luar penelitian.

Berdasarkan hasil uji simultan, diperoleh bahwa nilai $\left(\mathrm{F}_{\text {statistic }}\right)$ sebesar $0,010989<0,05$ maka $_{0}$ ditolak, artinya intangible asset, profitabilitas, dan sustainability report memiliki pengaruh signifikan terhadap terhadap nilai perusahaan (Tobin's Q) pada indeks Sri-Kehati secara simultan atau bersama-sama.

Tabel 8. Hasil Uji T

\begin{tabular}{ccccc}
\hline Variable & Coefficient & Std. Error & t-Statistic & Prob. \\
\hline C & 1.579373 & 0.582318 & 2.712217 & 0.0117 \\
IA & -0.127356 & 0.060981 & -2.088443 & 0.0467 \\
ROA & 43.55125 & 15.73619 & 2.767586 & 0.0103 \\
SR & 0.290855 & 0.519467 & 0.559911 & 0.5803 \\
\hline
\end{tabular}

Sumber : data sekunder yang diolah

Berdasarkan Tabel 8 dapat disimpulkan bahwa:

1. Variabel Intangible Asset $\left(\mathrm{x}_{1}\right)$ memiliki koefisien $-0,127356$ dengan nilai probabilitas $0,0467<0,05$, maka $\mathrm{H}_{0}$ ditolak yang berarti variabel intangible asset memiliki pengaruh secara parsial dengan arah negatif terhadap variabel nilai perusahaan periode 2009-2014

2. Variabel Proritabilitas $\left(\mathrm{x}_{2}\right)$ memiliki koefisien 43.55125 dengan nilai probabilitas $0,0103<0,05$, maka $\mathrm{H}_{0}$ ditolak yang berarti variabel profitabilitas memiliki pengaruh secara parsial dengan arah positif terhadap variabel nilai perusahaan periode 2009-2014

3. Variabel Sustainability Report $\left(\mathrm{x}_{3}\right)$ memiliki koefisien 0.290855 dengan nilai probabilitas 0,5803 $<0,05$, maka $\mathrm{H}_{0}$ ditolak yang berarti variabel Sustainability Report memiliki pengaruh secara parsial dengan arah positif terhadap variabel nilai perusahaan periode 2009-2014

\section{PEMBAHASAN}

Berdasarkan hasil pengujian secara parsial ditemukan bahwa variabel intangible asset memiliki nilai probabilitas sebesar 0,0467 yang lebih kecil dari 0,05 maka $\mathrm{H}_{0}$ ditolak artinya hasil pengujian menunjukkan bahwa variabel Intangible asset memiliki pengaruh signifikan terhadap nilai perusahaan. Hasil tersebut sesuai dengan hipotesis yang dibangun penulis. Selain itu, koefisien regresi pada variabel Intangible asset bernilai negatif yang menunjukkan bahwa setiap peningkatan satu satuan Intangible asset maka nilai perusahaan akan mengalami penurunan sebesar 0.127356 . Artinya, intangible asset berpengaruh secara signifikan dengan arah negatif terhadap nilai perusahaan. 
Hal ini disebabkan dalam perhitungan VAICTM terdapat tiga komponen. Komponen yang memberikan nilai tinggi, hanya berasal dari komponen VAHU (Value Added Human Capital). Vahu menunjukkan berapa banyak value added yang dihasilkan dengan dana yang dikeluarkan untuk karyawan. Perusahaan yang menganggarkan beban karyawan tinggi berharap akan mendapat value added yang tinggi dari karyawan, tetapi anggaran yang tinggi jika tidak diimbangi dengan pelatihan dan training justru akan menurunkan produktivitas karyawan. Karyawan yang tidak produktif dan beban karyawan yang tinggi akan menurunkan laba bersih sehingga menurunkan nilai perusahaan. Sedangkan, komponen yang memberikan nilai terendah VACA dimana unsur dalam VACA terdiri dari nilai ekuitas dan laba bersih. Padahal, pasar atau investor lebih mengutamakan melihat salah satu dari ketiga komponen intellectual capital yaitu VACA (capital employed) sebagai pertimbangan mereka dalam menempatkan nilai bagi perusahaan.

Berdasarkan hasil pengujian secara parsial ditemukan bahwa variabel profitabilitas memiliki nilai probabilitas

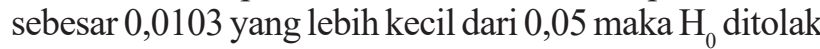
artinya hasil pengujian menunjukkan bahwa variabel profitabilitas memiliki pengaruh signifikan terhadap nilai perusahaan. Hasil tersebut sesuai dengan hipotesis yang dibangun penulis. Selain itu, koefisien regresi pada variabel profitabilitas bernilai positif yang menunjukkan bahwa setiap peningkatan satu satuan profitabilitas maka nilai perusahaan akan mengalami kenaikan sebesar 43,55125. Artinya, profitabilitas berpengaruh secara signifikan dengan arah positif terhadap nilai persusahaan. Hasil penelitian ini menunjukkan bahwa profitabilitas yang tinggi mencerminkan kemampuan perusahaan dalam menghasilkan laba atau profit yang tinggi sehingga nilai perusahaan juga tinggi. Profitabilitas yang tinggi akan mengindikasikan bahwa perusahaan memiliki keuangan yang sehat dan baik, sehingga dapat mempengaruhi investor dan calon investor untuk meningkatkan permintaan saham. Selanjutnya permintaan saham yang tinggi akan mempengaruhi harga saham perusahaan sehingga terjadi hubungan positif antara profitabilitas dengan harga saham yang dimana dampaknya akan mempengaruhi nilai perusahaan.

Berdasarkan hasil pengujian secara parsial ditemukan bahwa variabel sustainability report memiliki nilai probabilitas sebesar 5,038206 yang lebih besar dari 0,05 maka $\mathrm{H}_{0}$ diterima artinya hasil pengujian menunjukkan bahwa variabel sustainability report tidak memiliki pengaruh signifikan terhadap nilai perusahaan. Hasil tersebut tidak sesuai dengan hipotesis yang dibangun penulis. Selain itu, koefisien regresi pada variabel sustainability report bernilai positif yang menunjukkan bahwa setiap peningkatan satu satuan sustainability report maka nilai perusahaan akan mengalami kenaikan sebesar 0,290855. Hal ini disebabkan dalam membuat laporan ini bisa disebabkan beberapa hal, seperti tambahan biaya dan usaha dalam pembuatan laporan. Selain itu dengan belum adanya kewajiban dari regulator pasar modal terkait pelaporan ini juga membuat para emiten merasa belum butuh untuk menyiapkan laporan terkait. Sehingga menunjukkan investor pada indeks Sri-Kehati belum melihat elemen pada laporan tersebut sebagai bahan pertimbangan dalam mengambil keputusan.

\section{KESIMPULAN}

Berdasarkan hasil analisis deskriptif dan pengujian menggunakan model regresi data panel, diperoleh beberapa kesimpulan sebagai berikut:

1. Berdasarkan pengujian analisis deskriptif dapat disimpulkan bahwa :

a. Intangible asset pada perusahaan yang terdaftar pada indeks Sri-Kehati periode 2009-2014 memiliki nilai rata-rata sebesar 3.8121 dan standar deviasi sebesar 1.7208 lebih rendah dari nilai rata-rata sehingga menunjukkan bahwa nilai intangible asset berkelompok atau tidak bervariasi.

b. Nilai maksimum VAIC ${ }^{\text {TM }}$ adalah 7.5395 sedangkan nilai minimum sebesar -2.3600 dan nilai standar deviasi selama tahun 20092014 sebesar 0.0714 yang lebih rendah dari nilai rata-rata sehingga menunjukkan bahwa profitabilitas berkelompok atau tidak bervariasi. Profitabilitas pada perusahaan yang terdaftar pada indeks Sri-Kehati periode 2009 -2014 memiliki nilai rata-rata sebesar 0.1562 . Nilai maksimum ROA adalah 0.3378 sedangkan nilai minimum sebesar -0.0338 .

c. Sustainability report pada perusahaan yang terdaftar pada indeks Sri-Kehati periode 2009 -2014 memiliki nilai rata-rata sebesar 0.6751 dan standar deviasi sebesar 0.2684 yang lebih rendah dari nilai rata-rata sehingga menunjukkan bahwa nilai sustainability report tahun 20092014 berkelompok atau tidak bervariasi. Nilai maksimum SRDI adalah 0.9341 sedangkan nilai minimum selama periode penelitian sebesar -0.1538 .

2. Secara simultan intangible asset, profitabilitas, dan sustainability report mempunyai pengaruh yang signifikan dengan arah positif terhadap nilai perusahaan pada perusahaan yang terdaftar di Indeks Sri-Kehati periode 2009-2014.

3. Pengaruh secara parsial terhadap nilai perusahaan pada perusahaan yang terdaftar di Indeks Sri-Kehati periode 2009-2014:

(a) Intangible asset memiliki pengaruh negatif signifikan terhadap nilai perusahaan;(b) Profitabilitas memiliki pengaruh positif signifikan terhadap nilai perusahaan; dan (c) Sustainability report tidak memiliki pengaruh signifikan terhadap nilai perusahaan. 


\section{DAFTAR PUSTAKA}

Almajali, Dr. Amal Yassin. 2012. Factors Affecting the Financial Performanceof Jordanian Insurance Companies Listed at Amman Stock Exchange. Journal of Management Research ISSN 1941899X 2012,Vol. 4,No.2.

Chen, Li-Ju., dan Chen, Shun-Yu. 2011. The influence of profitability on firm value with capital structure as the mediator and firm size and industry as moderators. Investment Management and Financial Innovations journal, Volume 8, Issue 3, 2011.

Coopers, P., 2004. Management of Non-Performing Assets by Indian Banks. IBA Bulletin, 26(1), pp.6197.

Erawati, N.M.A., Sudana. I.P., 2009. "Intellectual capital, Nilai perusahaan, dan Kinerja Keuangan". Makalah Akuntansi, Fakultas Ekonomi, Universitas Udayana.

Florence Katthy Mawikere dan Jantje J. Tinangon. 2016. Analisis Penerapan ISAK No 14 Tahun 2010 Tentang Aset Tidak Berwujud dan Biaya Website Pada PT Bunaken Surya Wisata Tour and Travel.

Gill, Amarjit dan Obradovich, John. 2012. The Impact of Corporate Governance and Financial Leverage on the Value of American Firms. International Research Journal of Finance and Economics. ISSN 1450-2887 Issue 91.

Hatane, Semuel dan Josua tarigan (2014) Pengungkapan Sustainability Report dan Kinerja Keuangan. Jurnal akuntansi dan Keuangan VO. 16 Universitas Kristen Petra.

Hermuningsih, S., 2013. Pengaruh Profitabilitas. Growth.

Hery. 2015. Analisis Laporan Keuangan. Edisi 1. Yogyakarta: Center For Academic Publishing Services.

Ikatan Akuntan Indonesia. 2009. Pernyataan Standar Akuntansi Keuangan (PSAK) No. 1 Penyajian Laporan Keuangan (Revisi 2009). Jakarta :Salemba Empat.

Lazonick, W. and O'sullivan, M., 2000. Maximizing shareholder value: a new ideology for corporate governance. Economy and society, 29(1), pp.13-35.

Moniaga, Fernandez. Struktur Modal, Profitabilitas dan struktur Biaya terhadap Nilai Perusahan Industri Keramik, Porcelen dan Kaca.

Munawaroh, A., 2015. Pengaruh Profitabilitas Terhadap Nilai Perusahaan dengan Corporate Social Responsibilty Sebagai Variabel Moderating. Jurnal Ilmu dan Riset Akuntansi, 3(4).

Nurmayasari, Andi. 2012. Analisis Pengaruh Profitabilitas, Ukuran Perusahaan, Leverage, dan Kebijakan Dividen terhadap Nilai Perusahaan (Studi Kasus pada Perusahaan Manufaktur di BEI Tahun
2007-2010). Skripsi. Fakultas Ekonomi Universitas Islam Indonesia, Yogyakarta.

Prastika, Ni Gst. Ayu Pt. S. 2012. Pengaruh Ios, Leverage, Dan Dividend Yield Terhadap Profitabilitas Dan Nilai Perusahaan Sektor Manufaktur Di BEI. Jurnal Magister Manajemen Universitas Udayana.

Rachmawati, Damar Asih Dwi.2012. Pengaruh Intellectual Capital Terhadap Return On Asset (ROA). Jurnal Nominal. Volume 1.No. 1. 2012.

Setia, Lukas.2008. Teori dan Praktik Manajemen Keuangan. Yogyakarta :ANDI.

Soraya, Lesta dan Muchamad Syafrudin .2013. Pengaruh Nilai Asset Tidak Berwujud dan Penelitian dan Pengembangan terhadap Nilai Pasar Perusahaan. E-Jurnal S1 Universitas Diponegoro Volume 2 Nomor Tahun 2013. ISSN : 2337-3806.

Sucuahi, W. and Cambarihan, J.M., 2016. Influence of Profitability to the Firm Value of Diversified Companies in the Philippines. Accounting and Finance Research, 5(2), p.149.

Sugiyono, P.D., 2013. Metode Penelitian Manajemen. Bandung: ALFABETA, CV.

Ulum, Ihyaul. 2008. Intellectual Capital Performance Sektor Perbankan di Indonesia. Jurnal Akuntansi dan Keuangan. 10(2), 77-84.

Utami, Wiwik. 2015. Financial performance and quality of sustainability disclosure based on global reporting. Mediterranean Journal of Social Sciences (MCSER) Publishing, Rome-Italy. ISSN 2039-2117.

Wedgandt, J.J., Kimmel, P.D. and Kieso, D.E., 2013. Financial Accounting: IFRS Editon.

Wibowo A dan Sekar akrom. 2014. Dampak pengungkapan sustainability report terhadap kinerja keuangan dan pasar perusahaan. SNA 17 Mataram 2014.

Widhiastuti, Ni Luh P dan Made Yenni L. 2015. Pengaruh Return On Asset dan Intangible Asset terhadap Nilai Perusahaan dengan Corporate Social Rensposibility sebagai Variabel Pemoderasi. E-Jurnal Akuntansi Universitas Udayana 11.2 (2015): 370-38. ISSN: 2302-8556.

www.duniainvestasi.com [Tanggal akses terakhir 26 Oktober 2016]

www.idx.co.id[Tanggal akses terakhir 26 Oktober 2016]

www.kehati.or.id [Tanggal akses terakhir 02 Desember 2016]

www.sahamok.com [Tanggal akses terakhir 25 Februari 2017]

www.sindonews.com[Tanggal akses terakhir 26 Oktober 2016]

Yuniasih, Ni Wayan dkk. 2010. Eksplorasi Kinerja Pasar Perusahaan : Kajian berdasarkan Modal intelektual. Makalah Disampaikan dalam Simposium Nasional Akuntansi XIII. Purwokerto : 13-15 Oktober. 


\section{LAMPIRAN}

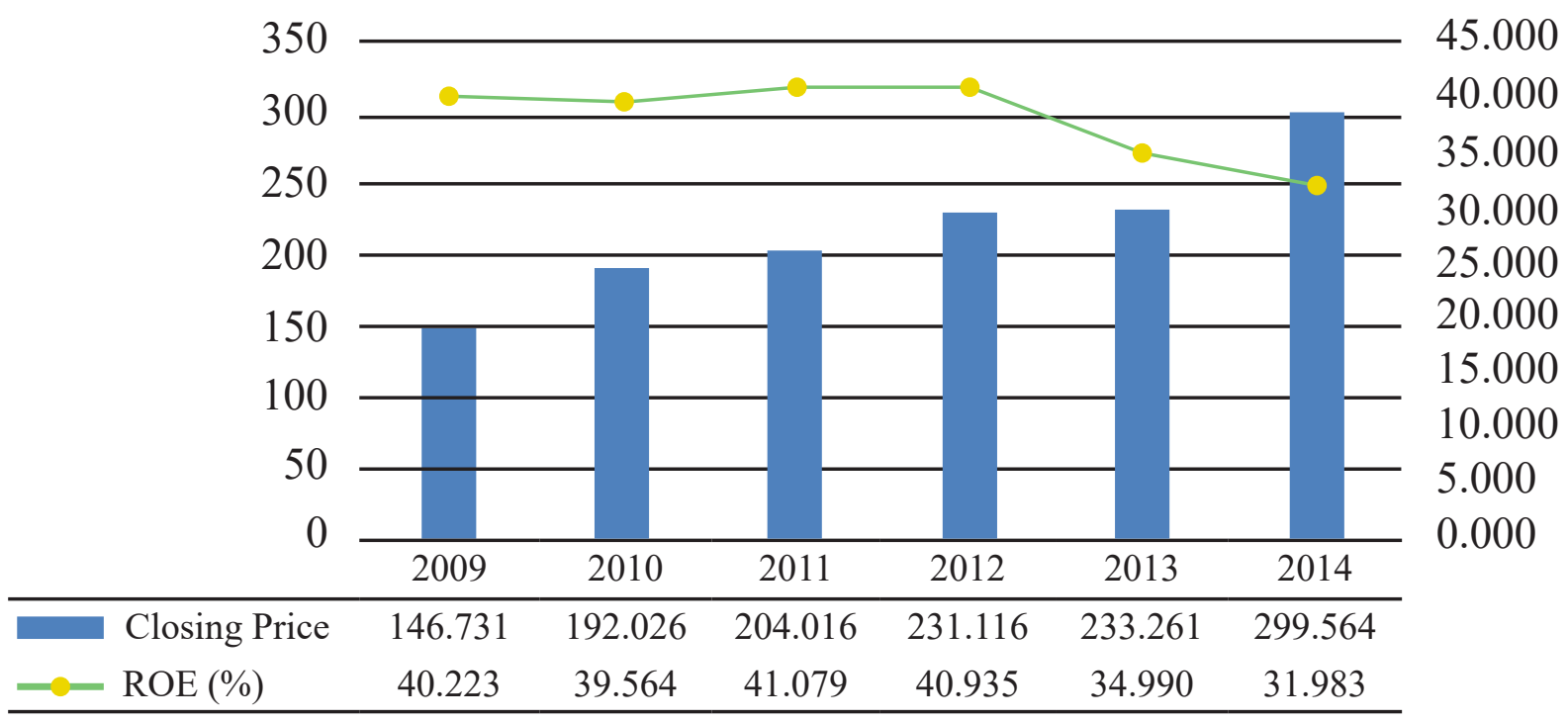

Closing Price $\quad-\quad-$ ROE (\%)

Sumber : www.duniainvestasi.com dan www.idx.co.id, data diolah oleh penulis (2016)

Gambar 1. Pergerakan Indeks Saham dan Return On Equity Sri Kehati periode 2009-2014

Tabel 1. Operasionalisasi Variabel

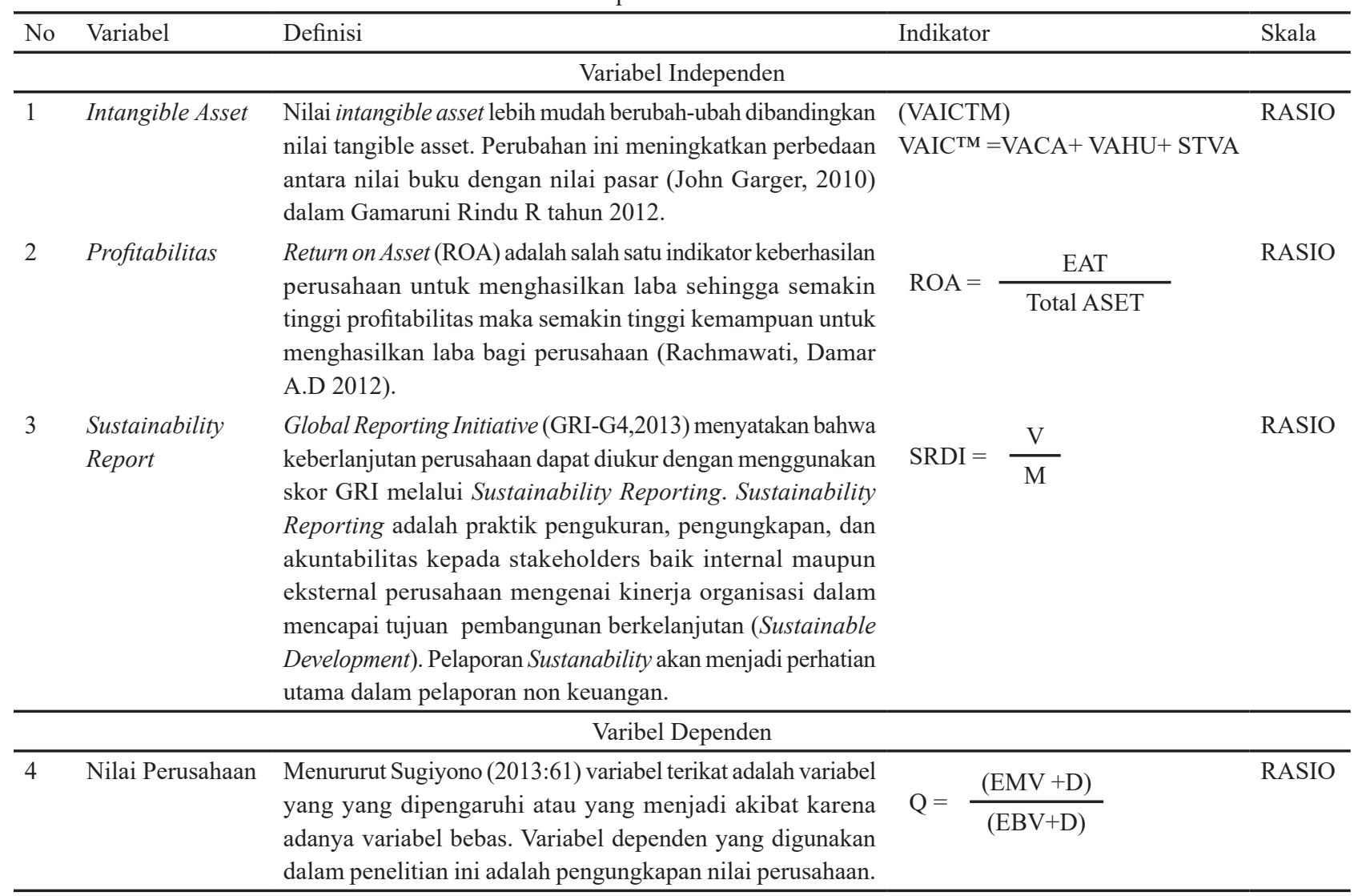

